\title{
Sodium Alginate Supplementation Plus HIIT and MICT Can Induce CCK and PYY Increment in Men With Metabolic Syndrome
}

\section{Alireza Ebrahimi}

University of Mazandaran

Mohammad azizi ( $\sim$ azizimihammad@gmail.com )

Razi University of Kermanshah: Razi University https://orcid.org/0000-0002-6386-7344

Worya Tahmasebi

Razi University of Kermanshah: Razi University

Rastegar Hoseini

Razi University of Kermanshah: Razi University

\section{Research}

Keywords: Metabolic Syndrome, Exercise, Appetite, Health, Dietary Fiber

Posted Date: September 22nd, 2021

DOI: https://doi.org/10.21203/rs.3.rs-907817/v1

License: (c) (i) This work is licensed under a Creative Commons Attribution 4.0 International License. Read Full License 


\section{Abstract}

Background: Abdominal obesity is a common phenomenon in metabolic syndrome (MetS). Inducing satiety by weight management plays an important role in reducing the risk of obesity and consequently MetS. This study was investigated effect of sodium alginate supplementation plus HIIT and MICT on CCK and PYY increment in MetS men.

Methods: For this purpose, 40 men with MetS volunteered and were randomly divided into five groups as follow: HIIT groups with supplement $\left(n=8,4 * 4\right.$ min bouts at $85-95 \%$ of $\mathrm{HR}_{\text {peak, }}$ with 3 min of active recovery at $50-70 \% \mathrm{HR}_{\text {peak }}, 3$ ses/week), HIIT ( $\mathrm{n}=8,4 * 4$ min bouts at $85-95 \%$ of $\mathrm{HR}_{\text {peak, }}$ with 3 min of active recovery at $50-70 \% \mathrm{HR}_{\text {peak }}, 3$ ses/week), MICT with supplement ( $\mathrm{n}=8,30 \mathrm{~min}$ at $60-70 \% \mathrm{HR}_{\text {peak }}, 3$ ses/week), MICT ( $n=8,30$ min at $60-70 \% \mathrm{HR}_{\text {peak, }} 3$ ses/week) and control group ( $n=8$, no exercise). The $\mathrm{HITT}+\mathrm{S}$ and MICT+S groups consumed $1.5 \mathrm{~g}$ of Sigma sodium alginate (made in the USA) solution in $100 \mathrm{mg}$ of sweet water ( $7 \mathrm{~g}$ of fructose), 30 minutes before 3 main meals three days per week during 8 weeks.

Results: After 8 weeks of interventions, CCK and PYY were markedly increased in the studied groups, this increase was significantly greater in the HIIT+S than other groups. Also, the MetS Z score was significantly decreased in all studied groups and this decrease was significantly higher in the HIIT+S than other groups $(P<0.05)$.

Conclusion: The results showed that HIIT and MICT led to an overall improvement in men with MetS. However, combining sodium alginate supplementation triggers these improvements.

Trial registration: IRCT20190916044788N1. Registered 12 march 2020, https://www.irct.ir/

\section{Introduction}

Metabolic syndrome (MetS) encompasses a cluster of metabolic disorders including abdominal obesity, hypertension, dyslipidemia, and insulin resistance [1]. Among them, abdominal obesity is characterized by increased distribution of fat in the central area of the body, which potentially increases the risk of insulin resistance, hypertension, cardiovascular disease and cancer [2]. The National Cholesterol Education Program (NCEP) Adult Treatment Panel III (ATP III) defines the MetS as having at least three of these disorders: systolic and diastolic blood pressure (SBP and DBP) more than 130 and $85 \mathrm{mmHg}$, respectively, waist circumference (WC) more than $102 \mathrm{~cm}$ (for men) or $88 \mathrm{~cm}$ (for women), fasting blood sugar (FBS) more than $100 \mathrm{mg} / \mathrm{dl}$. fasting triglyceride (TG) more than $150 \mathrm{mg} / \mathrm{dl}$, high-density lipoprotein (HDL) cholesterol less than $40 \mathrm{mg} / \mathrm{dl}$ (for men) or $50 \mathrm{mg} / \mathrm{dl}$ (for women) [3]. Evidence suggests that adherence to regular physical activity and healthy dietary pattern may trigger changes in the expression of circulating appetite-related hormones and/or metabolites and sensations of hunger and satiety, and these responses also appear to depend on exercise intensity in which is important to weight management [4]. 
Cholecystokinin (CCK), Glucagon-like peptide-1 (GLP-1), Oxyntomodulin (OXM), peptide YY (PYY) (which are secreted from the small and large intestine), and pancreatic and amylin polypeptides (which both them are secreted from the pancreas) are hormones that affect appetite and hunger and satiety signaling [5]. Unlike other anti-appetite hormones, PYY increases energy consumption along with reducing appetite [6]. Therefore, it has been shown that increased PYY secretion after food consumption may decrease the risk of obesity [7].

High-intensity interval training (HIIT), and moderate-intensity interval training (MICT) are known to be among common non-pharmacological protocols for metabolism controlling and associated condition such as obesity by regulating hunger, satiety, and appetite perception [8].Several studies have reported the importance of MICT in improving body composition, cardiovascular fitness, insulin resistance (IR), and lipid profile [8-10]. While other investigations show similar physiological adaptation after either HIIT or MICT [11]. In addition to the beneficial effects of MICT and HIIT in appetite perception and plasma levels of appetite hormones [12], Matos et al (2017) reported contradictory results [13].

Furthermore, intake of dietary fiber has been identified to preventive effects on the mentioned metabolic disorders especially obesity [14]. As a dietary fiber, alginate is a jelly polysaccharide and a structural component extracted from brown seaweed. Sodium alginate is the most commonly used alginate, which has been widely used as an additive in the food industry in recent years. Consumption of sodium alginate seems to modulate human appetite by gelling it in the stomach [15]. Sodium alginate affects gastric emptying and promotes a feeling of satiety. consequence, stimulates the appetite hormones secretion (CCK, GLP-1, and PYY) [14, 16].

Despite evidence for the positive adaptations following HIIT compared with MICT concerning aerobic fitness and vascular function, it is still unclear which form of training is most effective for weight control, overall fat loss, or central adiposity [17]. Since limited studies have conducted on the interactional effects of sodium alginate supplementation with different exercise methods on weight loss, body fat, and appetite hormones in people with MetS [18], the present study aimed to investigate the effect of eight weeks of HIIT and MICT with sodium alginate supplementation on CCK and PYY levels in men with MetS.

\section{Materials And Methods}

\section{Study design and Participants}

This semi-experimental study was performed on forty men (18-34 years old) were selected according to our research criteria among volunteers (Fig. 1). The present study was approved by the Ethics Committee of Razi University at Kermanshah (Ethical NO: IR.KUMS.REC.1398.214) and registered in the Iranian Clinical Trial Registration Center under the code IRCT20190916044788N1. The informed consent form was filled out by all participants.

Subjects with MetS based on the NCEP- ATP III [3] who had no history of cardiovascular disease, diabetes, thyroid, kidney, or cancer also did not have a regular exercise or diet plan for the past six months 
were included to this study. Initially we assessed 65 subjects in which 22 of them were excluded duo to not meeting inclusion criteria and wanting to participate in the study. After that 43 young men with MetS volunteered and were randomly divided into five groups: HIIT, high-intensity interval training + sodium alginate supplementation $(\mathrm{HIIT}+\mathrm{S})$, MICT, moderate-intensity interval training + sodium alginate supplementation (MICT $+S$ ), and control (C) (Fig. 1). Considering the obtained random number table, subjects are chosen. After that, they allocate to control and intervention groups.

\section{Measurements}

The participants' height and Bodyweight (BW) were measured by using the Seca scale (made by Hamburg Germany) with a measuring accuracy of $0.5 \mathrm{~cm}$ and $100 \mathrm{~g}$, respectively; body mass index (BMI) was calculated accordingly by dividing weight $(\mathrm{kg})$ to height square $\left(\mathrm{m}^{2}\right)$. WC was measured on the top of the iliac crest by using a non- starched and flexible tape with an accuracy of $1 \mathrm{~cm}$ [19]. Body fat percentage (BFP) was determined by using the bioelectrical impedance analysis (made in Korea, ZEUS 9.9 PLUS model). SBP and DBP was measured twice at 5 min intervals by using a Richter digital barometer (Richampion 1725145 made in Germany) from the right carotid artery and then the average was recorded [19].

\section{Diet and exercise control}

To minimize the effect of nutrition, all participants were asked to list all their food intake in the 24-hour food recall form 7 days before the first blood sampling and they were asked not to change their normal diet. They were also asked to avoid intense exercise and alcohol and caffeine drinking 48 hours before the blood sampling. The results were analyzed by NUTRITIONIST IV software based on the United States Department of Agriculture Food Composition Table that was modified for Iranian foods. Table 1 shows the fat, protein, carbohydrate, and total energy consumption values.

Table 1

$\mathrm{M} \pm \mathrm{SD}$ Food intake between groups

\begin{tabular}{|c|c|c|c|c|c|}
\hline & HITT $(n=8)$ & $\begin{array}{l}\text { HITT + S (n= } \\
\text { 8) }\end{array}$ & MICT $(n=8)$ & $\begin{array}{l}\text { MICT }+S(n= \\
\text { 8) }\end{array}$ & $C(n=8)$ \\
\hline $\begin{array}{l}\text { Energy } \\
\text { intake(Kcal) }\end{array}$ & $\begin{array}{l}3021.5 \pm \\
402.7\end{array}$ & $2651 \pm 289.6$ & $\begin{array}{l}2912.1 \pm \\
345.1\end{array}$ & $\begin{array}{l}2768.4 \pm \\
411.2\end{array}$ & $\begin{array}{l}2813.2 \pm \\
354.4\end{array}$ \\
\hline Carbohydrate(g) & $\begin{array}{l}377.6 \pm \\
118.2\end{array}$ & $357.8 \pm 123.1$ & $\begin{array}{l}414.9 \pm \\
121.6\end{array}$ & $380.7 \pm 117.8$ & $379.7 \pm 122.5$ \\
\hline Protein(g) & $135.9 \pm 41.4$ & $112.6 \pm 38.7$ & $87.3 \pm 40.7$ & $96.9 \pm 42.6$ & $112.5 \pm 39.3$ \\
\hline Fat(g) & $107.4 \pm 30.7$ & $85.4 \pm 29.4$ & $100.3 \pm 27.5$ & $95.3 \pm 28$ & $938 \pm 28.6$ \\
\hline
\end{tabular}




\section{Intervention}

\section{Sodium alginate supplementation}

The HITT + S and MICT + S groups consumed $1.5 \mathrm{~g}$ of Sigma sodium alginate (made in the USA) solution in $100 \mathrm{mg}$ of sweet water ( $7 \mathrm{~g}$ of fructose), 30 minutes before 3 main meals for three days per week during 8 weeks intervention.

\section{Exercise protocol}

The HIIT and MICT were trained three times per week. Both HIIT and MICT were preceded by a 10 min warm-up and terminated with a $10 \mathrm{~min}$ cool-down. MICT sessions were $30 \mathrm{~min}$ at a target intensity of $60-70 \%$ HR or rated perceived exertion (RPE) of $11-13$. The HIIT consisted of 4 bouts of 4 min intervals at $85-95 \%$ HR peak/RPE of 15-17, separated by 3 min active recovery at $50-70 \%$ HR peak (Fig. 2) [20].

\section{Appetite perception questionnaire}

To assess the subjective appetite, a Visual Analogue Scale (VAS) questionnaire was used. This questionnaire was used in most studies that measured the appetite indirectly. It consists of four questions that measured hunger, satiety, individual feeling to satiety, and individual feeling to eating desire. Subjects were asked to fill the questionnaire before exercise, immediately after exercise, 3-h postexercise, and 9-h post-exercise [20]. The questions are defined as below:

1. How strong is your desire to eat? (very weak to very strong).

2. How hungry do you feel? (not hungry too as hungry as I've ever felt).

3. How full do you feel? (not full at all to very full).

4. How much food do you think you could eat? (nothing at all to a large amount).

The average appetite score was calculated using the following formula:

Appetite score $=($ desire to eat + hunger $+(100$-fullness $)+$ prospective consumption $) / 4$ [4] .

Biochemical indicators measurement

$8 \mathrm{cc}$ blood samples were collected in a sitting position after 20 minutes of rest from the left-hand antecubital vein of the studied subjects 48 hours before and after the intervention, after $12 \mathrm{~h}$ fasting. To isolate serum, blood samples were centrifuged at $4^{\circ} \mathrm{C}$ for $15 \mathrm{~min}$ at $2500 \mathrm{rpm}$ and all samples were frozen and stored at $-80^{\circ} \mathrm{C}$ immediately until analysis.

The FBS was measured by enzymatic colorimetric assay (Glucose oxidase, Pars Azmon Co, Tehran, Iran). HDL cholesterol and TG were measured by using cholesterol oxidase phenol-amino antipyrin and the enzymatic method of glycerol 3-phosphate oxidase phenol-amino pyridine, respectively [21]; The insulin 
resistance index was calculated by multiplying the fasting glucose concentration $(\mathrm{mg} / \mathrm{dl})$ by the fasting insulin concentration $(\mu \mathrm{U} / \mathrm{mL})$ divided by the constant-coefficient 405 :

HOMA-IR= (fasting glucose $[\mathrm{mg} / \mathrm{dL}]) \times[$ fasting insulin $\{\mu \mathrm{U} / \mathrm{mL}\}] \div 405)[19]$.

The CCK levels (Zellbio kit, made in Germany with a sensitivity of $0.5 \mathrm{ng} / \mathrm{l}$ ) and PYY levels (Zellbio kit, made in Germany with a sensitivity of $1.5 \mathrm{Pg} / \mathrm{ml}$ ) were measured using the ELISA method.

\section{Data Analysis}

All statistical analyses were performed using the SPSS statistical software (version 21; SPSS Inc., Chicago, IL, USA) in which was used at a significant level of $P<0.05$. The Shapiro-Wilk's test was used for evaluating the normality of distribution. To compare the mean metabolic factors between and within groups, ANOVA and paired sample t-test were used, respectively. Tukey's post hoc test was used if significant differences were found.

\section{Results}

In current study, overall, 40 young men completed during the intervention study and three subjects were excluded because of not willing to continue, family and personal reasons. Based on the results, there were significant differences in the mean of age, BW and BMI between the pre-test and post-test conditions in the studied groups (Table 2).

After eight weeks intervention, BW and BMI were significantly decreased in four intervention groups $(\mathrm{P}<$ 0.001). The mean of BW was significantly different between the studied groups after intervention $(P=$ 0.009). The results of Tukey's post hoc test showed no significant difference in BW and BMI between the studied intervention groups; there was a significant difference between the HIIT and MIIT + S and the control in the BW (Table 2). 
Table 2

Anthropometric and primary characteristics of the subjects

\begin{tabular}{|c|c|c|c|c|c|c|}
\hline Variables & HIIT $(n=8)$ & $\begin{array}{l}\text { HIIT + S (n = } \\
8)\end{array}$ & $\begin{array}{l}\text { MICT }(n= \\
8)\end{array}$ & $\begin{array}{l}\text { MICT + S (n } \\
=8)\end{array}$ & $C(n=8)$ & $\begin{array}{l}\text { P-Value } \\
\text { a }\end{array}$ \\
\hline Age & $\begin{array}{l}20.88 \pm \\
1.55\end{array}$ & $24.4 \pm 4.17$ & $25.87 \pm 3.6$ & $24.62 \pm 2.32$ & $\begin{array}{l}22.87 \pm \\
4.32\end{array}$ & 0.491 \\
\hline Height & $\begin{array}{l}173.75 \pm \\
4.77\end{array}$ & $\begin{array}{l}176.25 \pm \\
6.73\end{array}$ & $\begin{array}{l}174.62 \pm \\
5.95\end{array}$ & $177.38 \pm 4.27$ & $179 \pm 6$ & 0.362 \\
\hline \multicolumn{7}{|c|}{$\begin{array}{l}\text { Bodyweight } \\
\text { (kg) }\end{array}$} \\
\hline Before & $\begin{array}{l}94.21 \pm \\
3.09\end{array}$ & $92.87 \pm 3.39$ & $\begin{array}{l}94.01 \pm \\
4.67\end{array}$ & $92.32 \pm 3.33$ & $\begin{array}{l}92.41 \pm \\
2.37\end{array}$ & 0.714 \\
\hline After & $\begin{array}{l}91.97 \pm \\
3.39^{a}\end{array}$ & $87.75 \pm 3.34$ & $\begin{array}{l}91.57 \pm \\
4.96\end{array}$ & $88.44 \pm 3.83^{a}$ & $\begin{array}{l}92.8 \pm \\
6.69\end{array}$ & $0.009^{¥}$ \\
\hline P Value ${ }^{b}$ & $0.001^{\star}$ & $0.001^{*}$ & $0.001^{*}$ & $0.001^{*}$ & 0.401 & \\
\hline \multicolumn{7}{|c|}{ BMI (kg/m2) } \\
\hline Before & $\begin{array}{l}31.28 \pm \\
2.29\end{array}$ & $30.03 \pm 2.83$ & $\begin{array}{l}30.95 \pm \\
3.07\end{array}$ & $29.4 \pm 1.97$ & $\begin{array}{l}28.94 \pm \\
2.24\end{array}$ & 0.306 \\
\hline After & $\begin{array}{l}30.54 \pm \\
2.27\end{array}$ & $28.37 \pm 2.7$ & $\begin{array}{l}30.16 \pm \\
3.15\end{array}$ & $28.16 \pm 2.09$ & $\begin{array}{l}28.95 \pm \\
2.27\end{array}$ & 0.265 \\
\hline P Value ${ }^{b}$ & $0.001^{*}$ & $0.001^{*}$ & $0.001^{*}$ & $0.001^{*}$ & 0.130 & \\
\hline \multicolumn{7}{|c|}{$\begin{array}{l}\text { P values with superscript "a" are calculated using one-way analysis of variance test followed by post } \\
\text { hoc Tukey's test; superscript letter "b" indicates values are calculated using paired t-test }\end{array}$} \\
\hline \multicolumn{7}{|c|}{ *: Significantly different in comparison pre and post-test within the groups } \\
\hline \multicolumn{7}{|c|}{$¥:$ significantly different in comparison with pre and post-test between groups. } \\
\hline
\end{tabular}

After eight weeks intervention, WHR, TG, FBS, and MetS Z-score significantly decreased, and HDL significantly increased in all studied groups (Table 3). The results of one-way ANOVA showed no significant difference in all variables between the groups in the pre-test. However, in the post-test, there was a significant difference in all variables (except for WHR and HDL) between the groups. The results of Tukey's post hoc test show a significant difference between the studied groups and the control in the MetS Z-score (Table 3). 
Table 3

Changes in MetS risk factors and MetS z-scores in all groups

\begin{tabular}{|c|c|c|c|c|c|c|}
\hline Variables & HIIT $(n=8)$ & $\begin{array}{l}\text { HIIT }+S(n= \\
\text { 8) }\end{array}$ & MICT $(n=8)$ & $\begin{array}{l}\text { MICT + S (n } \\
=8)\end{array}$ & $C(n=8)$ & $\begin{array}{l}\text { P- } \\
\text { Value a }\end{array}$ \\
\hline \multicolumn{7}{|l|}{ WHR (cm) } \\
\hline Before & $\begin{array}{l}0.93 \pm \\
0.001\end{array}$ & $0.93 \pm 0.002$ & $0.94 \pm 0.003$ & $0.93 \pm 0.002$ & $0.94 \pm 0.02$ & 0.466 \\
\hline After & $\begin{array}{l}0.91 \pm \\
0.002\end{array}$ & $0.92 \pm 0.004$ & $0.92 \pm 0.007$ & $0.92 \pm 0.005$ & $0.94 \pm 0.03$ & 0.087 \\
\hline P Value ${ }^{b}$ & $0.004^{\star}$ & $0.026^{*}$ & $0.016^{*}$ & $0.003^{*}$ & 0.540 & \\
\hline \multicolumn{7}{|l|}{$\begin{array}{l}\text { SBP } \\
(\mathrm{mmHg})\end{array}$} \\
\hline Before & $12.72 \pm 0.6$ & $13.48 \pm 0.6$ & $13.53 \pm .41$ & $13.55 \pm .46$ & $14.2 \pm 0.53$ & 0.052 \\
\hline After & $\begin{array}{l}12.42 \pm \\
0.21^{a}\end{array}$ & $\begin{array}{l}12.43 \pm \\
0.77^{a}\end{array}$ & $12.31 \pm .93^{a}$ & $12 \pm 1.01^{a}$ & $\begin{array}{l}13.96 \pm \\
0.52\end{array}$ & $0.001^{¥}$ \\
\hline$P$ Value $^{\mathrm{b}}$ & 0.242 & $0.002^{\star}$ & $0.035^{\star}$ & $0.003^{*}$ & 0.152 & \\
\hline \multicolumn{7}{|c|}{$\mathrm{DBP}(\mathrm{mmHg})$} \\
\hline Before & $7.73 \pm 1.09$ & $7.98 \pm 0.92$ & $8.47 \pm .0 .55$ & $7.55 \pm 1.12$ & $7.98 \pm 1.1$ & 0.405 \\
\hline After & $\begin{array}{l}7.88 \pm \\
0.46^{a}\end{array}$ & $7.82 \pm 0.54$ & $7.92 \pm .49$ & $7.5 \pm 0.55$ & $8 \pm 0.43$ & $0.011^{*}$ \\
\hline$P$ Value $b$ & 0.623 & 0.489 & $0.003^{*}$ & 0.908 & 0.820 & \\
\hline \multicolumn{7}{|c|}{ TG (mg/dl) } \\
\hline Before & $\begin{array}{l}159.5 \pm \\
19.16\end{array}$ & $\begin{array}{l}170.5 \pm \\
24.76\end{array}$ & $\begin{array}{l}177.38 \pm \\
12.72\end{array}$ & $\begin{array}{l}176.38 \pm \\
12.76\end{array}$ & $\begin{array}{l}169.25 \pm \\
13.31\end{array}$ & 0.187 \\
\hline After & $\begin{array}{l}141.88 \pm \\
19.24\end{array}$ & $\begin{array}{l}129.25 \pm \\
9.34^{\mathrm{a \varphi}}\end{array}$ & $\begin{array}{l}159.12 \pm \\
14.03^{\beta}\end{array}$ & $136 \pm 14.32^{a}$ & $\begin{array}{l}172.25 \pm \\
11.32\end{array}$ & $0.001^{¥}$ \\
\hline
\end{tabular}

$P$ values with superscript "a" are calculated using one-way analysis of variance test followed by post hoc Tukey's test; superscript letter "b" indicates values are calculated using paired t-test

*: Significantly different in comparison pre and post-test within the groups

¥: significantly different in comparison with pre and post-test between groups.

a. Significant differences with the control

$\varphi$ : Significant differences with the MICT

B: Significant differences with the MICT+S 


\begin{tabular}{|c|c|c|c|c|c|c|}
\hline Variables & HIIT $(n=8)$ & $\begin{array}{l}\text { HIIT + S (n = } \\
8)\end{array}$ & MICT $(n=8)$ & $\begin{array}{l}\text { MICT + S (n } \\
=8)\end{array}$ & $C(n=8)$ & $\begin{array}{l}\text { P- } \\
\text { Value a }\end{array}$ \\
\hline P Value & $0.001^{*}$ & $0.001^{\star}$ & $0.001^{\star}$ & $0.001^{*}$ & 0.370 & \\
\hline \multicolumn{7}{|c|}{ HDL (mg/dl) } \\
\hline Before & $36.8 \pm 4.75$ & $31.72 \pm 3.12$ & $36.5 \pm 7.78$ & $33.37 \pm 8.15$ & $\begin{array}{l}34.55 \pm \\
9.12\end{array}$ & 0.501 \\
\hline After & $\begin{array}{l}39.65 \pm \\
4.75\end{array}$ & $39.6 \pm 6.25$ & $39.37 \pm 7.32$ & $38.87 \pm 7.8$ & $33.43 \pm 1$ & 0.128 \\
\hline P Value & $0.002^{\star}$ & $0.001^{\star}$ & $0.001^{\star}$ & $0.001^{*}$ & 0.310 & \\
\hline \multicolumn{7}{|c|}{ FBS(UL/ml) } \\
\hline Before & $\begin{array}{l}97.72 \pm \\
12.25\end{array}$ & $\begin{array}{l}89.66 \pm \\
10.75\end{array}$ & $100.75 \pm 4.2$ & $\begin{array}{l}93.25 \pm \\
10.96\end{array}$ & $87.63 \pm 14$ & 0.122 \\
\hline After & $88.03 \pm 8$ & $78.7 \pm 5^{a \varphi}$ & $91.75 \pm 5.28$ & $83.5 \pm 5.85$ & $\begin{array}{l}75.9 \pm \\
12.93\end{array}$ & $0.007^{¥}$ \\
\hline P Value & $0.001^{\star}$ & $0.004^{\star}$ & $0.001 *$ & $0.016^{*}$ & $0.031^{\star}$ & \\
\hline \multicolumn{7}{|c|}{ MetS Z-score } \\
\hline Before & $\begin{array}{l}0.519 \pm \\
0.38\end{array}$ & $\begin{array}{l}0.725 \pm \\
0.457\end{array}$ & $\begin{array}{l}0.863 \pm \\
0.263\end{array}$ & $\begin{array}{l}0.852 \pm \\
0.277\end{array}$ & $\begin{array}{l}0.668 \pm \\
0.24\end{array}$ & 0.240 \\
\hline After & $\begin{array}{l}-0.036 \pm \\
0.21^{a}\end{array}$ & $\begin{array}{l}0.242 \pm \\
0.11^{a \varphi}\end{array}$ & $\begin{array}{l}0.25 \pm \\
0.196^{a}\end{array}$ & $\begin{array}{l}0.074 \pm \\
0.122^{a}\end{array}$ & $\begin{array}{l}0.848 \pm \\
0.219\end{array}$ & $0.001^{*}$ \\
\hline P Value & $0.001^{\star}$ & $0.001^{*}$ & $0.001 *$ & $0.001 *$ & 0.820 & \\
\hline \multicolumn{7}{|c|}{$\begin{array}{l}\text { P values with superscript "a" are calculated using one-way analysis of variance test followed by post } \\
\text { hoc Tukey's test; superscript letter "b" indicates values are calculated using paired t-test }\end{array}$} \\
\hline \multicolumn{7}{|c|}{ *: Significantly different in comparison pre and post-test within the groups } \\
\hline \multicolumn{7}{|c|}{$¥:$ significantly different in comparison with pre and post-test between groups. } \\
\hline \multicolumn{7}{|c|}{ a. Significant differences with the control } \\
\hline \multicolumn{7}{|c|}{$\varphi$ : Significant differences with the MICT } \\
\hline
\end{tabular}

The results of Table 4 show that appetite was significantly decreased in all four studied groups immediately, three, and nine hours after exercise compared to pre-exercise. Also, appetite immediately after exercise in all four studied groups was significantly less than three, and nine hours after exercise ( $P$ $<0.05)$. Appetite suppression immediately after HIIT was more than MICT $(P<0.05)$. 
Table 4

Changes in appetite in all groups

\begin{tabular}{|c|c|c|c|c|}
\hline Variables & HITT $(n=8)$ & HITT + S $(n=8)$ & MICT $(n=8)$ & MICT + S $(n=8)$ \\
\hline \multicolumn{5}{|c|}{ Appetite before exercise } \\
\hline Before & $23.2 \pm 6.44$ & $32.5 \pm 9.02$ & $24.25 \pm 9.77$ & $34.93 \pm 9.77$ \\
\hline After & $21.02 \pm 5.31$ & $28.83 \pm 8.43$ & $22.33 \pm 9.13$ & $31.56 \pm 9.13$ \\
\hline P Value & $0.006^{\star}$ & $0.027^{\star}$ & $0.003^{\star}$ & $0.003^{\star}$ \\
\hline \multicolumn{5}{|c|}{ Appetite after exercise } \\
\hline Before & $23.2 \pm 6.44$ & $21.37 \pm 8.24$ & $16.5 \pm 6.06$ & $26.96 \pm 9.39$ \\
\hline After & $18.02 \pm 5.31$ & $13.06 \pm 2.3$ & $13.88 \pm 3.98$ & $20.98 \pm 10.44$ \\
\hline P Value & $0.006^{*}$ & $0.014^{*}$ & $0.007^{\star}$ & $0.020 *$ \\
\hline \multicolumn{5}{|c|}{ Appetite 3 h p } \\
\hline Before & $59.72 \pm 16.38$ & $67.27 \pm 11.96$ & $57.05 \pm 14.44$ & $48.48 \pm 17.02$ \\
\hline After & $39.1 \pm 12.5$ & $26.85 \pm 8.35$ & $41.18 \pm 7.17$ & $23.76 \pm 5.97$ \\
\hline P Value & $0.001^{*}$ & $0.001^{*}$ & $0.001^{\star}$ & $0.001^{\star}$ \\
\hline \multicolumn{5}{|c|}{ Appetite $9 \mathrm{~h} \mathrm{p}$} \\
\hline Before & $74.8 \pm 10.73$ & $76.57 \pm 10.64$ & $75.91 \pm 13.02$ & $64.26 \pm 6.22$ \\
\hline After & $35.97 \pm 10.82$ & $18.93 \pm 5.33$ & $43.71 \pm 13.32$ & $22.58 \pm 5.74$ \\
\hline P Value & $0.001^{*}$ & $0.001^{*}$ & $0.001^{*}$ & $0.001^{*}$ \\
\hline
\end{tabular}

HIIT: high-intensity interval training; HIIT + S: high-intensity interval training + sodium alginate supplementation; MICT: moderate-intensity interval training; MICT + S: moderate-intensity interval training + sodium alginate supplementation; $\mathrm{C}$ : that had neither aerobic training nor sodium alginate supplementation.

*: Significantly different in comparison pre and post-test within the groups

Appetite before exercise: Appetite changes immediately before exercise.

Appetite after exercise: Appetite changes immediately after exercise.

Appetite $3 \mathrm{~h}$ p: Appetite changes 3 hours after exercise.

Appetite $9 \mathrm{~h}$ p: Appetite changes 9 hours after exercise.

The results of Fig. 3 show that compared to the pre-test CCK concentration was significantly increased in $\mathrm{HIIT}+\mathrm{S}, \mathrm{HIIT}, \mathrm{MICT}+\mathrm{S}$, and MICT + S. Also, there was a significant difference between HIIT + S and MICT $+S$ compared to the control $(P=0.009, P=0.023)$. 
According to Fig. 4, PYY increased significantly in the HIIT + S, HIIT, MICT + S, and MICT compared to preexercise. Also, there was a significant increase in the MICT $+S(P=0.002)$ and the HIIT $+S(P=0.002)$ compared to the control.

\section{Discussion}

According to NCEPATP III guidelines, one of the primary treatments for all MetS risk factors is weight loss and increased physical activity [22]. The results of current study showed the improvements of subject's MetS Z score in the HIIT + S group was more than in the other studied groups. Ramos et al. (2017) compared the three types of exercise (HIIT1, HIIT4, MICT) and concluded that HIIT1 is more effective than HIIT4 and MICT in improving MetS and reducing z scores [23]. The mechanism responsible for improvement of MetS following exercise is likely related to changes in energy balance [24], circulating lipids, and insulin sensitivity [25]. Also, an increase in HDL may be due to increased activity of the lipoprotein lipase (LPL); the LPL enzyme in the conversion of VLDL to HDL works through increasing the C-HDL activity [26]. Exercise activities can stimulate lipid oxidation and inhibit lipid synthesis within the liver, which is mediated by activating the AMPK pathway. The stimulation and activation of this enzyme with increased AMP to ATP ratio in the tissue is another possible result of the physiological stimulus of exercise activity [27]. Sodium alginate supplementation is shown to improve insulin sensitivity, hyperinsulinemia, and hyperleptinemia, and attenuate inflammation in white adipose tissue and inhibit hepatic lipid synthesis. It also reduces oxidative stress and increases antioxidant enzyme levels in the liver [28].

Our results showed a significant increase in CCK and PYY after eight weeks of HIIT and MICT in men with MetS. This increase in the HIIT + S group was greater than in the other groups. While Ueda et al (2013) reported ghrelin concentration significantly increased while there was no significant change in GLP-1 and PYY following 12 weeks of aerobic training [29]. Martins et al (2017) reported no significant effect on appetite and plasma ghrelin levels, GLP- 1, PYY, and CCK before and after MICT and HIIT [12]. Holmstrup et al (2013) also reported that MICT (1h) and HIIT (5-minute bouts) had no significant effect on plasma PYY values [30]. In contrast, Jones et al (2009) reported an increased PYY of about 23\% compared to the pretest. Differences in the exercise protocol, age, and gender might be the possible explanations of the contradictory results.

However, increased anti-appetite agents (PYY, CCK) reflect the optimal effects of exercise on suppressing appetite and decrease total energy intake [31]. The main mechanism for PYY responses induced by exercise is not well understood [32].

Generally, PYY is known to be affected by signals such as CCK, gastric acid, calcitonin gene-related peptide, luminal bile salts, and insulin-like growth factor-1 [33]. Potential increases in sympathetic nervous system activity and catecholamines may also increase the PYY secretion from the intestinal cells. Exercise-induced PYY increment might reduce NPY receptors expression in orchid nuclei via acting on Y2 receptors in the hypothalamus [6]. It is to be noted that HIIT and MICT with or without 
supplementation improved MetS Z score in favor of the HIIT + S. Comparing MICT with HIIT, Ramos et al (2017) reported the reduction of the overall MetS Z score after HIIT [23], while, Bateman et al (2011) after MICT [34] and Batacan et al (2017) reported no significant improvement [10].

Increased hormone-sensitive lipase (HSL) activity induced by exercise through AMP kinase activation, increased epinephrine and glucagon activity, and downstream events cause lipolysis and free fatty acids released from adipose tissue and intracellular TG concentration [9]. Lipid oxidation provides strong evidence for the role of exercise adaptation in improving blood lipid profiles through [35] increased lipoprotein lipase (LPL) activity and hydrolyzing TG and LDL [9]. Compared to other groups, HIIT + S decreased FBS more significantly in this study.

An increase in PGC1a expression in skeletal muscle following exercise might be one of the possible mechanisms that increase glucose uptake from blood circulation, GLUT4 expression, and gluconeogenesis [35]. Exercise lowers blood glucose through insulin-stimulated and contraction-mediated pathways [36].

\section{Conclusions}

In summary, in the present study, after eight weeks of HIIT + S, HIIT, MICT + S, and MICT, significant increases were observed in CCK and PYY levels. Therefore, it can be concluded that exercise and sodium alginate supplementation may be effective in suppressing appetite, increasing appetite hormones, and decreasing the risk factors for MetS. Further studies are needed to determine the effect of HIIT and MICT on appetite hormones, at different intensities and durations, as well as different doses of sodium alginate supplementation.

\section{Declarations}

\section{Ethics approval and consent to participate:}

The present study was approved by the Ethics Committee of Razi University at Kermanshah-Iran. The informed consent form was filled out by all participants.

\section{Availability of data and materials:}

All data is available

\section{Competing interests:}

The authors declare that they have no competing interests.

\section{Funding:}

There were no funding supports. 
Authors' contributions:

A.E and M.A research design and data collecting and manuscript writing. W.T and R.H data analysis and manuscript writing.

\section{Acknowledgments:}

The authors would like to thank the subjects for their willing participation in this study.

\section{References}

1. Nolan PB, Carrick-Ranson G, Stinear JW, Reading SA, Dalleck LC. Prevalence of metabolic syndrome and metabolic syndrome components in young adults: A pooled analysis. Preventive medicine reports. 2017;7:211-5.

2. Engin A. The definition and prevalence of obesity and metabolic syndrome. Obesity and lipotoxicity. 2017:1-17.

3. Grundy SM, Cleeman JI, Daniels SR, Donato KA, Eckel RH, Franklin BA, et al. Diagnosis and management of the metabolic syndrome: an American Heart Association/National Heart, Lung, and Blood Institute scientific statement. Circulation. 2005;112(17):2735-52.

4. Poon E, Sun, F H, Chung, A, \& Wong, S. Post-Exercise Appetite and Ad Libitum Energy intake in Response to High-Intensity Interval Training versus Moderate-or Vigorous-Intensity Continuous raining among Physically Inactive Middle-Aged Adults. Nutrients. 2018;10:1408.

5. Stensel D. Exercise, appetite and appetite-regulating hormones: implications for food intake and weight control. Annals of nutrition and metabolism. 2010;57:36-42.

6. Batterham RL, Cowley MA, Small CJ, Herzog H, Cohen MA, Dakin CL, et al. Gut hormone PYY 3-36 physiologically inhibits food intake. Nature. 2002;418(6898):650.

7. Perry B, Wang Y. Appetite regulation and weight control: the role of gut hormones. Nutrition \& diabetes. 2012;2(1):e26.

8. Wang N, Liu Y, Ma Y, Wen D. High-intensity interval versus moderate-intensity continuous training: Superior metabolic benefits in diet-induced obesity mice. Life sciences. 2017;191:122-31.

9. Zhang JQ, Thomas TR, Ball SD. Effect of exercise timing on postprandial lipemia and HDL cholesterol subfractions. Journal of Applied Physiology. 1998;85(4):1516-22.

10. Batacan RB, Duncan MJ, Dalbo VJ, Tucker PS, Fenning AS. Effects of high-intensity interval training on cardiometabolic health: a systematic review and meta-analysis of intervention studies. $\mathrm{Br} \mathrm{J}$ Sports Med. 2017;51(6):494-503.

11. Camacho-Cardenosa A, Camacho-Cardenosa M, Burtscher M, Martínez-Guardado I, Timon R, BrazoSayavera J, et al. High-intensity interval training in normobaric hypoxia leads to greater body fat loss in overweight/obese women than high-intensity interval training in normoxia. Frontiers in physiology. 2018;9:60. 
12. Martins C, Aschehoug I, Ludviksen M, Holst J, Finlayson G, Wisloff U, et al. High-intensity interval training, appetite, and reward value of food in the obese. Medicine and science in sports and exercise. 2017;49(9):1851-8.

13. Matos VAF, de Souza DC, Browne RAV, dos Santos VOA, Costa EC, Fayh APT. Acute effect of highintensity interval exercise and moderate-intensity continuous exercise on appetite in overweight/obese males: a pilot study. Sport Sciences for Health. 2017;13(2):403-10.

14. Georg Jensen M, Pedersen C, Kristensen M, Frost G, Astrup A. efficacy of alginate supplementation in relation to appetite regulation and metabolic risk factors: evidence from animal and human studies. Obesity reviews. 2013;14(2):129-44.

15. Georg Jensen M, Kristensen M, Astrup A. Effect of alginate supplementation on weight loss in obese subjects completing a 12-wk energy-restricted diet: a randomized controlled trial. The American journal of clinical nutrition. 2012;96(1):5-13.

16. Wang X, Liu F, Gao Y, Xue C-h, Li RW, Tang Q-j. Transcriptome analysis revealed anti-obesity effects of the Sodium Alginate in high-fat diet-induced obese mice. International journal of biological macromolecules. 2018;115:861-70.

17. Wewege M, Van Den Berg R, Ward R, Keech A. The effects of high-intensity interval training vs. moderate-intensity continuous training on body composition in overweight and obese adults: a systematic review and meta-analysis. Obesity Reviews. 2017;18(6):635-46.

18. Kumar SA, Brown L. Seaweeds as potential therapeutic interventions for the metabolic syndrome. Reviews in Endocrine and Metabolic Disorders. 2013;14(3):299-308.

19. Canale MP, Manca di Villahermosa S, Martino G, Rovella V, Noce A, De Lorenzo A, et al. Obesityrelated metabolic syndrome: mechanisms of sympathetic overactivity. International journal of endocrinology. 2013;2013.

20. Savina C, Donini L, Anzivino R, De MF, De LB, Cannella C. Administering the" AHSP Questionnaire" (appetite, hunger, sensory perception) in a geriatric rehabilitation care. The journal of nutrition, health \& aging. 2003;7(6):385-9.

21. Kaminsky LA, Whaley MH. Evaluation of a new standardized ramp protocol: the BSU/Bruce Ramp protocol. Journal of Cardiopulmonary Rehabilitation and Prevention. 1998;18(6):438-44.

22. Carroll S, Dudfield M. What is the relationship between exercise and metabolic abnormalities? Sports medicine. 2004;34(6):371-418.

23. Ramos JS, Dalleck LC, Borrani F, Beetham KS, Wallen MP, Mallard AR, et al. Low-volume highintensity interval training is sufficient to ameliorate the severity of metabolic syndrome. Metabolic syndrome and related disorders. 2017;15(7):319-28.

24. van der Windt DJ, Sud V, Zhang H, Tsung A, Huang H. The effects of physical exercise on fatty liver disease. Gene Expression The Journal of Liver Research. 2018;18(2):89-101.

25. Hallsworth K, Fattakhova G, Hollingsworth KG, Thoma C, Moore S, Taylor R, et al. Resistance exercise reduces liver fat and its mediators in non-alcoholic fatty liver disease independent of weight loss. Gut. 2011;60(9):1278-83. 
26. Ferguson MA, Alderson NL, Trost SG, Essig DA, Burke JR, Durstine JL. Effects of four different single exercise sessions on lipids, lipoproteins, and lipoprotein lipase. Journal of applied physiology. 1998;85(3):1169-74.

27. Lavoie J-M, Gauthier M-S. Regulation of fat metabolism in the liver: link to non-alcoholic hepatic steatosis and impact of physical exercise. Cellular and Molecular Life Sciences CMLS. 2006;63(12):1393-409.

28. $\mathrm{Q}$ 姆. Sodium alginate prevents progression of non-alcoholic steatohepatitis and liver carcinogenesis in obese and diabetic mice: 怄区; 2016.

29. Ueda S-y, Miyamoto T, Nakahara H, Shishido T, Usui T, Katsura Y, et al. Effects of exercise training on gut hormone levels after a single bout of exercise in middle-aged Japanese women. Springerplus. 2013;2(1):83.

30. Holmstrup M, Fairchild T, Keslacy S, Weinstock R, Kanaley J. Satiety, but not total PYY, is increased with continuous and intermittent exercise. Obesity. 2013;21(10):2014-20.

31. Jones TE, Basilio J, Brophy P, McCammon M, Hickner R. Long-term exercise training in overweight adolescents improves plasma peptide YY and resistin. Obesity. 2009;17(6):1189-95.

32. Hallworth JR. The influence of exercise intensity on appetite regulating hormones GLP-1 and PYY in active healthy adults: Lethbridge, Alta: University of Lethbridge, Dept. of Kinesiology and ...; 2016.

33. Karra $E$, Chandarana K, Batterham RL. The role of peptide $Y Y$ in appetite regulation and obesity. The Journal of physiology. 2009;587(1):19-25.

34. Bateman LA, Slentz CA, Willis LH, Shields AT, Piner LW, Bales CW, et al. Comparison of aerobic versus resistance exercise training effects on metabolic syndrome (from the Studies of a Targeted Risk Reduction Intervention Through Defined Exercise-STRRIDE-AT/RT). The American journal of cardiology. 2011;108(6):838-44.

35. Kiwata JL, Dorff TB, Schroeder ET, Gross ME, Dieli-Conwright CM. A review of clinical effects associated with metabolic syndrome and exercise in prostate cancer patients. Prostate cancer and prostatic diseases. 2016;19(4):323.

36. Rowell LB, O'Leary DS, Kellogg Jr DL. Integration of cardiovascular control systems in dynamic exercise. Comprehensive physiology. 2010:770-838.

\section{Figures}




\section{CONSORT DIAGRAM: OBSERVATIONAL STUDY}

泀

Assessed for eligibility

$$
(n=65)
$$

Excluded $(n=22)$

- Not meeting inclusion criteria $(n=15)$

- $\quad$ Refused to participate $(n=7)$

Randomized $(n=43)$

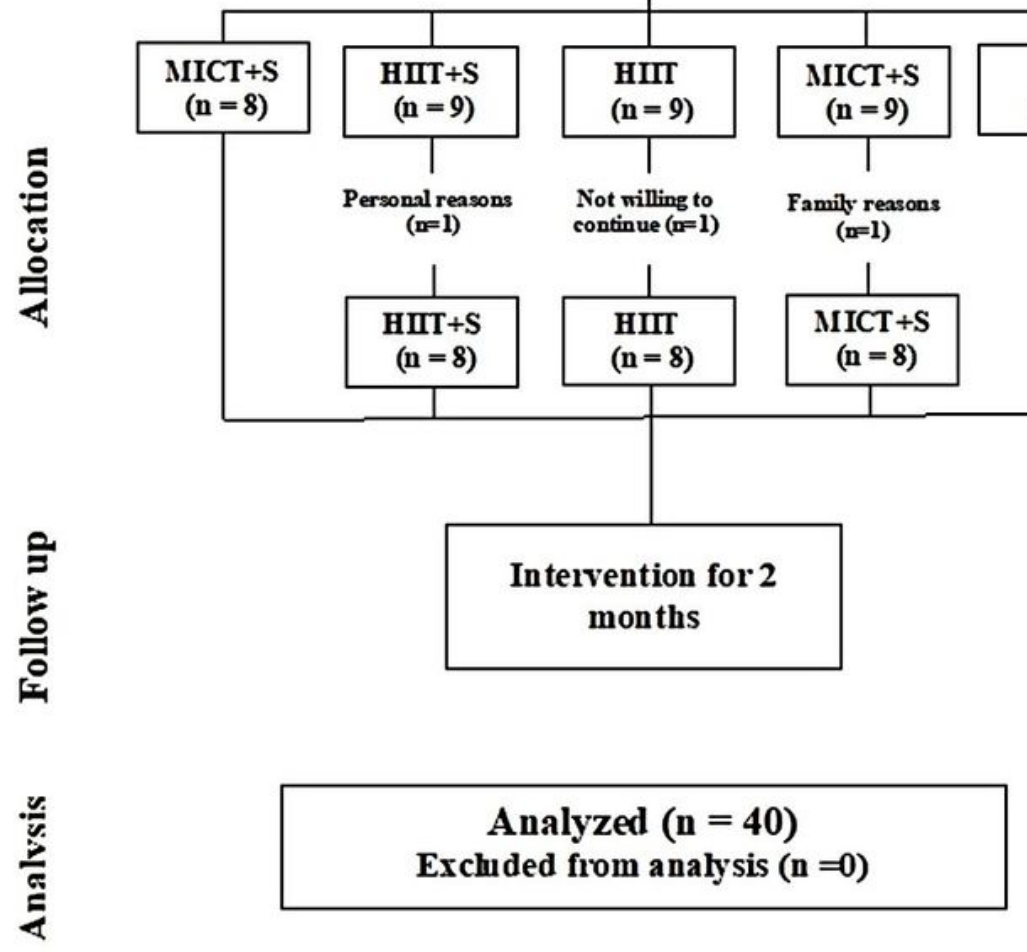

Figure 1

Flow diagram of the progress through the phases of a parallel randomized trial of five groups (that is, enrolment, intervention allocation, follow-up, and data analysis) 


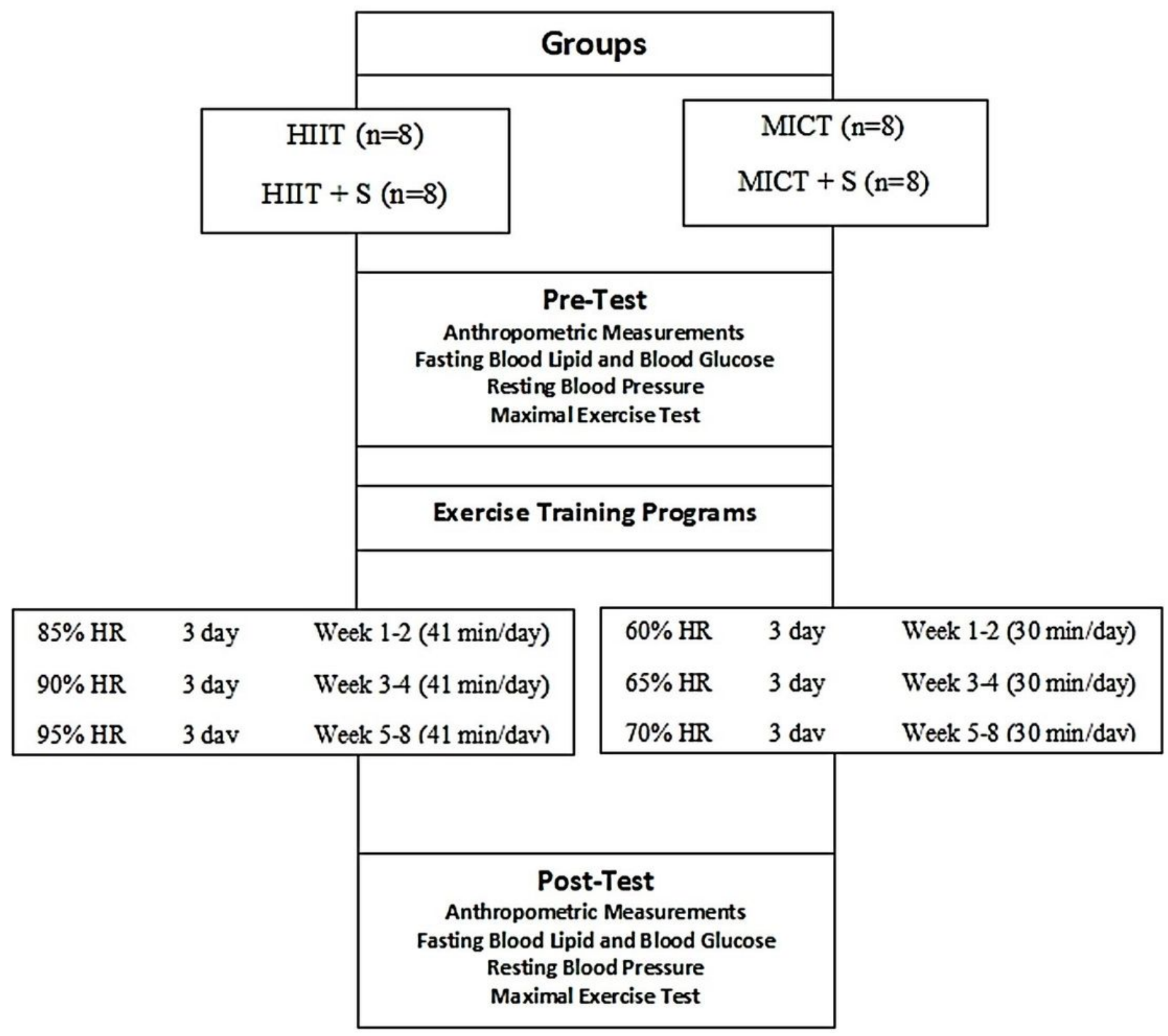

Figure 2

Exercise training program 


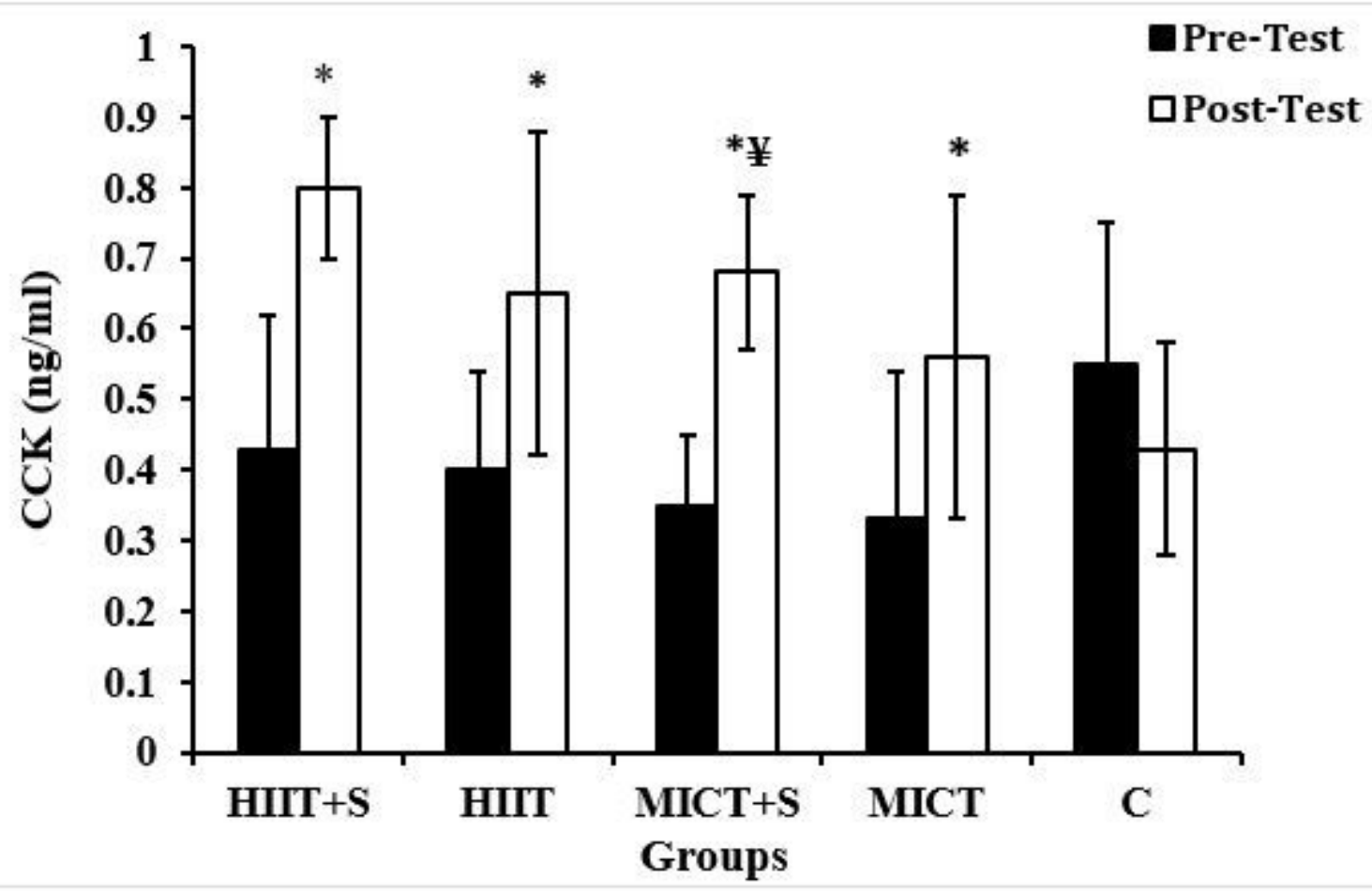

Figure 3

Comparison between mean \pm SD of CCK concentration between groups *: Significantly different in comparison pre and post-test within the groups ¥: Significant differences with the control

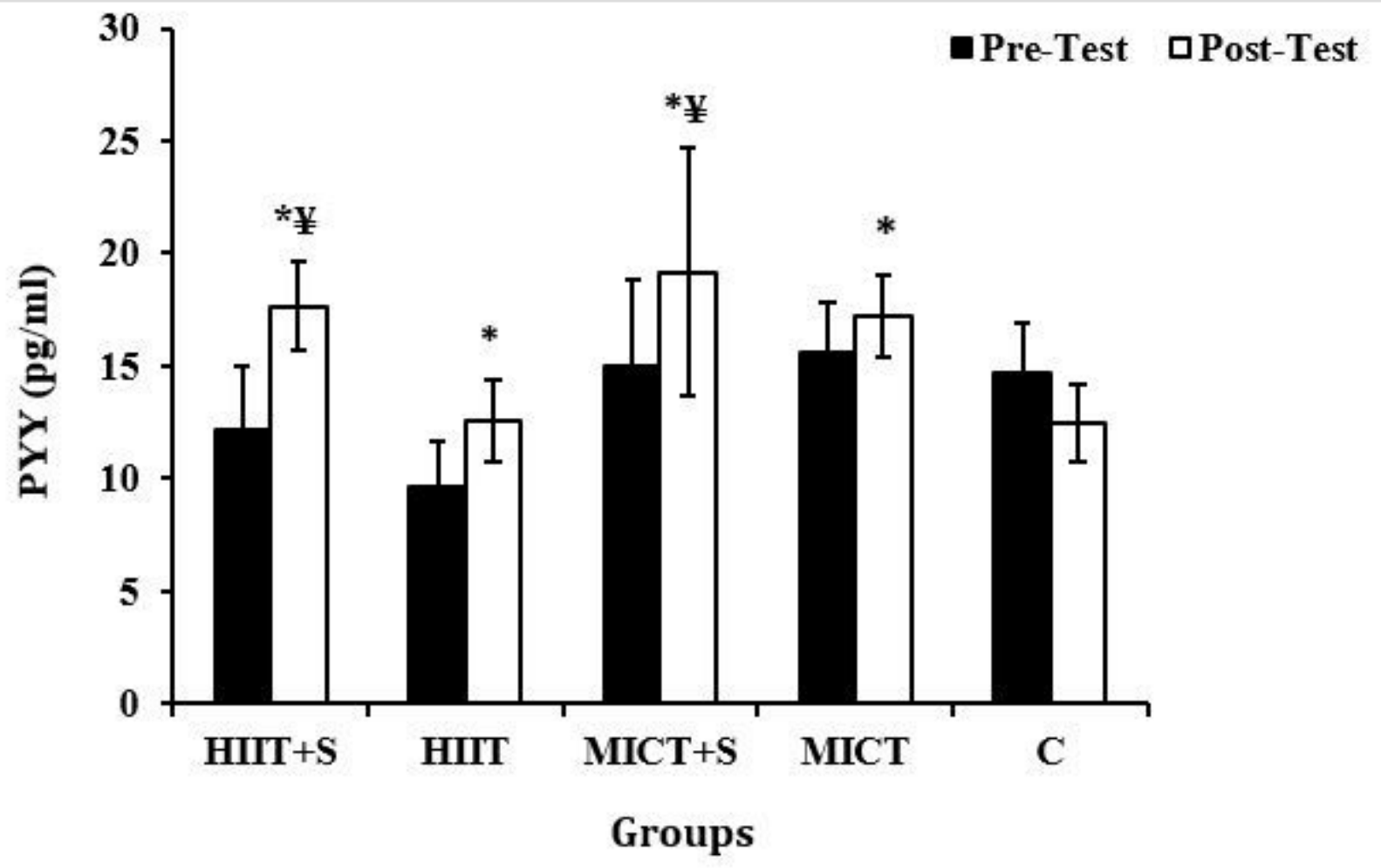

Figure 4 
Comparison between mean \pm SD of PYY concentration between groups *: Significantly different in comparison pre and post-test within the groups $¥$ : Significant differences with the control 